\title{
Genetic variability in Blanco Orejinegro breed cattle populations in Colombia
}

\author{
R. Martínez, A.P. Llinás and J.F. M.-Rocha \\ Centro de Biotecnología y Bioindustria, \\ Corporación Colombiana de Investigación Agropecuaria, Mosquera, Colombia \\ Corresponding author: J.F. M.-Rocha \\ E-mail: juanfelipemrocha@gmail.com
}

Genet. Mol. Res. 12 (2): 1083-1094 (2013)

Received June 1, 2012

Accepted September 12, 2012

Published April 10, 2013

DOI http://dx.doi.org/10.4238/2013.April.10.4

\begin{abstract}
We analyzed population structure and genetic diversity in Blanco Orejinegro Creole cattle with 12 microsatellite markers, genotyping 138 individuals belonging to 7 commercial and 3 conservation herds. These markers showed a high level of polymorphism; 171 alleles were identified. The mean number of alleles per locus was 5.63 (3.82-6.58). The total number of alleles per marker was 14.2 and ranged from 16 (TGLA126) to 22 (TGLA227). The mean expected heterozygosity (0.73) was higher than the observed heterozygosity $(0.65)$, with a significant excess of heterozygosity in almost all populations $\left(F_{\text {IS }}=0.09 ; \mathrm{P}<0.05\right)$. This may be due to crossing between different lines of this breed, affecting the inbreeding levels. Analysis of relationships among populations, assessed by principal component analysis and Nei's genetic distances, indicated a close relationship between some herds. Furthermore, analysis of population structure demonstrated a low probability of admixture with Zebu breeds, as it shows the cluster assignment and the $F_{\mathrm{ST}}$ values obtained. We conclude that there is high allelic diversity in this breed, even though a low effective population size has been maintained and the level of inbreeding has not been monitored. Therefore, appropriate conservation
\end{abstract}


efforts should be undertaken, such as adopting strategies aimed at minimizing inbreeding, to avoid losing genetic variability.

Key words: Genetic diversity; Microsatellite markers; Population genetic structure

\section{INTRODUCTION}

Nowadays, a number of distinct local Creole cattle breeds are found throughout the Americas. Creole cattle show great phenotypic heterogeneity and have adapted to a wide range of environments with few human interventions. The Blanco Orejinegro (BON) has been recognized as a Creole cattle breed with a broad geographical distribution and adapted to a wide range of environments, from the high Andean region to the harsh conditions in Colombian tropical regions.

In spite of the importance of this genetic resource adapted to the humid tropics, during the first decades of the past century the Creole breeds were indiscriminately crossbred with imported taurine breeds from temperate countries and also with zebuine breeds. This has contributed to the genetic erosion of an important tropical cattle genetic resource (Hall and Ruane, 1993). Today, Creole cattle account for only $0.01 \%$ of the national bovine population, and this proportion experienced a $23 \%$ decrease from 1989 to 1999 . The last population census available for BON reported a total size population of 3968 animals in 27 herds (Asocriollo, 2003).

Currently, a global awareness of the need to conserve the genetic diversity of lowproduction breeds is likely to contribute to current or future identification of traits of interest (Notter, 1999; Bruford et al., 2003; Toro, 2008) that are considered essential for maintaining future breeding options. Therefore, an estimate of the current genetic status and an evaluation of maintaining genetic variability are needed to support conservation programs of Colombian Creole cattle breeds. This can be accomplished by studying phenotypic, genealogical information or from molecular markers.

Microsatellite markers are abundant, well dispersed in the genome, and highly polymorphic. In addition, microsatellite markers have been shown to be useful for a variety of purposes, such as genome mapping, parentage determination, legal medicine, disease research, cancer research, and determination of genetic variation (Goldstein and Schötterer, 1999). Furthermore, microsatellites are currently the most common markers used for genetic characterization of cattle breeds (Kantanen et al., 2000; Cañón et al., 2001; Hanotte et al., 2002; Beja-Perira et al., 2003).

The aim of this study was to characterize the genetic variability of the Colombian Creole cattle breed BON as well as to estimate the genetic relationship between populations and with other common Zebu cattle breeds and assess the extent and pattern of gene admixture in the Creole cattle populations.

\section{MATERIAL AND METHODS}

\section{Samples and DNA extraction}

Blood samples were collected from a total of $138 \mathrm{BON}$ individuals belonging to com- 
mercial cattle herds located in the Departments of Antioquia (Campoalegre $=\mathrm{CA})$, Cundinamarca $($ El Palmar $=$ EP), Cordoba $($ La Esmeralda $=$ LE), Risaralda $($ Hato Viejo $=$ HV; Bohemia $=\mathrm{BH}$; Azufral $=\mathrm{AZ})$, and Tolima $($ Pacora $=\mathrm{JP})$. Samples were also collected from animals of cattle herds belonging to the Colombian National University (UNAL), Antioquia University (UDEA), and the Germplasm Bank of the breed kept by Colombian Corporation for Agricultural Research (BG), all of which were located in the Department of Antioquia. Samples were also collected from 18 Zebu breed animals. The number of individuals for each herd and their location are shown in Table 1.

\begin{tabular}{|c|c|c|c|}
\hline Subpopulation & Location & Department & $\mathrm{N}$ \\
\hline $\mathrm{AZ}$ & La Virginia & Risaralda & 10 \\
\hline $\mathrm{BH}$ & La Virginia & Risaralda & 10 \\
\hline CA & Fredonia & Antioquia & 6 \\
\hline EP & Pacho & Cundinamarca & 11 \\
\hline $\mathrm{HV}$ & La Virginia & Risaralda & 10 \\
\hline JP & Chaparral & Tolima & 7 \\
\hline LE & Ayapel & Córdoba & 17 \\
\hline UDEA & Gómez plata & Antioquia & 9 \\
\hline UNAL & Barbosa & Antioquia & 10 \\
\hline BG & San Roque & Antioquia & 12 \\
\hline
\end{tabular}

\section{Genetic characterization}

All analyses were performed at the Animal Molecular Genetics Laboratory of the Colombian Corporation of Agricultural Research. Genomic DNA was extracted from whole blood using 20\% Chelex.

Blood was collected in Eppendorf tubes with PBL. After adding $170 \mu \mathrm{L}$ previously prepared $20 \%$ Chelex to each tube, the samples were incubated in a water bath preheated to $56^{\circ} \mathrm{C}$ for $30 \mathrm{~min}$. The tubes were then placed in a beaker containing distilled water previously heated to boiling and allowed to float gently for $8 \mathrm{~min}$. Next, the tubes were centrifuged for 3 min at 15,000 rpm. Afterwards, the supernatant containing the concentrated DNA was pipetted off and added to a new Eppendorf tube. The extracted DNA samples were stored at $-20^{\circ} \mathrm{C}$.

\section{Microsatellite genotyping}

We used 12 STR markers that were recommended by Food and Agriculture Organization (FAO, 2011) and International Society of Animal Genetics (ISAG) for cattle diversity studies: BM2113, BM1818, BM1824, ETH10, ETH225, ETH3, INRA23, SPS115, TGLA122, TGLA126, TGLA 227, and TGLA 53. Microsatellites were amplified in a multiplex PCR assay. Each PCR tube with a final volume of $10 \mu \mathrm{L}$ contained 30-100 ng genomic DNA, 100 $\mu \mathrm{M}$ of each dNTP, 1.0 U DNA polymerase (AmpliTaq Gold DNA Polymerase, Applied Biosystems), 4-20 $\mu \mathrm{M}$ labeled forward primer and unlabeled reverse primer (depending on each primer), and $50 \mu \mathrm{M} \mathrm{MgCl}_{2}$. The amplification was carried out in an iCycler (Biorad) thermo- 
cycler and the PCR cycling conditions employed were as follows: an initial denaturation step at $95^{\circ} \mathrm{C}$ for $10 \mathrm{~min}$ followed by 37 cycles of denaturation at $94^{\circ} \mathrm{C}$ for $75 \mathrm{~s}$, annealing at $56^{\circ} \mathrm{C}$ for $75 \mathrm{~s}$ (increasing $0.1^{\circ} \mathrm{C}$ in each cycle), and extension at $72^{\circ} \mathrm{C}$ for $90 \mathrm{~s}$, and a final extension at $72^{\circ} \mathrm{C}$ for $60 \mathrm{~min}$. The fluorescent labeled PCR products were mixed with Hi Di formamide and Liz $500^{\mathrm{TM}}$ internal size standard, denatured at $95^{\circ} \mathrm{C}$ for $5 \mathrm{~min}$ and genotyped on a capillary electrophoresis ABI PRISM ${ }^{\circledR} 310$ DNA analyzer (Applied Biosystems).

\section{Statistical analyses}

The microsatellite size analysis was performed using the GENEMAPPER 4.1 software package. The observed $\left(H_{\mathrm{O}}\right)$ and expected $\left(H_{\mathrm{E}}\right)$ heterozygosities, the F-statistics, the factor analysis of correspondence, and $F_{\text {IS }}$ value per population were calculated using the GENETIX version 4.05 software (Belkhir et al., 2003; http:kimura.univ-montp2.fr/genetix/). The polymorphic information content (PIC) value was calculated using the formula of Botstein et al. (1980), in addition to Excel "Microsatellite Toolkit version 3.1" (Park, 2001), using MS EXCEL 2007. Genetic distances were determined using the method of Nei (1972), with the module Gendist ${ }^{\mathbb{B}}$ included in the Phylip software (Felsenstein, 2004; http://evolution.genetics. washington.edu/phylip.html), and a prior process of bootstrapping resampling of 10,000, using the SEQBOOT module. The reconstruction of phylogenetic trees was performed using the neighbor-joining method (Saitou and Nei, 1987) with a package included in the same software.

The STRUCTURE version 2.1 program (Pritchard et al., 2000; http://pritch.bsd. uchicago.edu/software.html) was used to estimate the racial purity of the population model based on a clustering method that allows inference of population structure using genotype data from unlinked markers. This method assigns individuals to populations and identifies migrants and individuals combined. It assumes a model in which there are K populations, each of which is characterized by a profile frequency of alleles at each locus. Each individual is assigned a probability to a population or jointly to two or more populations if their genotype indicates that an individual is mixed. The most probable number of populations $(\mathrm{K})$ given the observed genotypic data was estimated by performing 1 run for each $\mathrm{K}(\mathrm{K} 3)$ with burn-in length and MCMC of 10,000 iterations.

\section{RESULTS}

A total of 171 allelic variants were detected from the 12 microsatellite loci evaluated, with an average of 14.2 alleles per marker. The mean number of alleles $\left(N_{\mathrm{A}}\right)$ per locus varied significantly and ranged from 3.82 to 6.58 . The TGLA227 marker showed the highest number (22 alleles), whereas the lowest number (16 alleles) was found in the TGLA126 marker. All 12 markers were polymorphic in the BON populations, where none of them showed variants with frequencies above 0.95 . The highest $N_{\mathrm{A}}$ was found in the LE cattle population with a mean of 6.58 alleles per locus, followed by values for BG (6.42) and CA (6.25) and the lowest value found in the EP population (3.82 alleles).

The average PIC value was 0.63 , where there was substantial variation in PIC among the markers. Table 2 shows the PIC values for each population; the highest PIC values were found for the populations of BG and UDEA $(0.866)$ and the lowest value was found for the $\mathrm{BH}$ population (0.71). In summary, all markers evaluated were highly informative with PIC values greater than 0.70 . 


\begin{tabular}{|c|c|c|}
\hline Subpopulation & $N_{\mathrm{A}}($ mean $)$ & PIC \\
\hline AZ & 5.25 & 0.82 \\
\hline BG & 6.42 & 0.86 \\
\hline $\mathrm{BH}$ & 4.83 & 0.71 \\
\hline CA & 6.25 & 0.77 \\
\hline Zebu & 5.58 & 0.78 \\
\hline EP & 3.82 & 0.72 \\
\hline $\mathrm{HV}$ & 4.33 & 0.74 \\
\hline JP & 4.25 & 0.77 \\
\hline LE & 6.58 & 0.81 \\
\hline UDEA & 5.58 & 0.86 \\
\hline UNAL & 4.58 & 0.76 \\
\hline
\end{tabular}

For abbreviations, see legend to Table 1.

\section{Values of heterozygosity per population}

Table 3 shows the $H_{\mathrm{O}}$ and $H_{\mathrm{E}}$ along with the $F_{\text {IS }}$ values obtained from the 12 microsatellite loci in the 11 herds analyzed (including the Zebu herd). An average $H_{\mathrm{E}}$ value of 0.73 was found, with the highest value found for population CA (0.7855). Similarly, the populations LE, CA and UDEA showed values above 0.75 , while the lowest value was found in the JP population (0.67).

The $H_{\mathrm{O}}$ per population ranged from $0.52(\mathrm{CA})$ to $0.72(\mathrm{BH})$ with a mean of 0.65 . The highest values were obtained for the $\mathrm{BH}$ and LE populations, whereas the lowest values were found in the CA and HV herds.

\section{Measures of genetic variability}

The mean $F_{\text {IS }}$ value, which can be used as an estimate of inbreeding, was found to be 0.09 across the populations tested, with the highest value in the CA herd (0.32) and the lowest value in the EP herd (-0.004).

\begin{tabular}{lccc} 
Table 3. Expected $\left(H_{\mathrm{E}}\right)$ and observed $\left(H_{\mathrm{O}}\right)$ heterozygosities and $F_{\text {IS }}$ for each subpopulation. \\
\hline Subpopulation & $H_{\mathrm{E}}$ & $H_{\mathrm{O}}$ & $F_{\text {IS }}$ \\
\hline AZ & 0.7365 & 0.7049 & 0.043 \\
BG & 0.7829 & 0.6027 & 0.2302 \\
BH & 0.7030 & 0.7297 & -0.038 \\
CA & 0.7855 & 0.5296 & 0.3257 \\
Zebu & 0.6888 & 0.6325 & 0.0816 \\
EP & 0.6846 & 0.6870 & -0.004 \\
HV & 0.7470 & 0.5960 & 0.2021 \\
JP & 0.6784 & 0.7044 & -0.038 \\
LE & 0.7649 & 0.7088 & 0.0734 \\
UDEA & 0.7598 & 0.6591 & 0.1326 \\
UNAL & 0.7049 & 0.6944 & 0.0149 \\
Average & 0.7306 & 0.6590 & 0.0930 \\
\hline
\end{tabular}

For abbreviations, see legend to Table 1.

In two populations (BG and HV), the average $F_{\text {IS }}$ values were higher than 0.2. Conversely, three populations $(\mathrm{BH}, \mathrm{JP}$, and $\mathrm{EP})$ had negative values $(-0.03,-0.03$, and -0.004 , 
respectively), showing an excess of heterozygotes and indicating possible crossbreeding between different lines of the same breed, thereby affecting the inbreeding level.

\section{Principal component analysis}

A spatial representation of each animal in the 10 populations of the Colombian Creole cattle breed BON are depicted in Figure 1. The first factorial axis explained $35.49 \%$ of the total variation, with greater variability found in the population BG (lower right side, in blue) and less variation found in the other populations of the BON breed, which were grouped very close to the right of the centroid. The second axis explained $16.88 \%$ of the variation and showed that Zebu breeds were grouped (left side, in pink) more homogeneously than the BON populations.

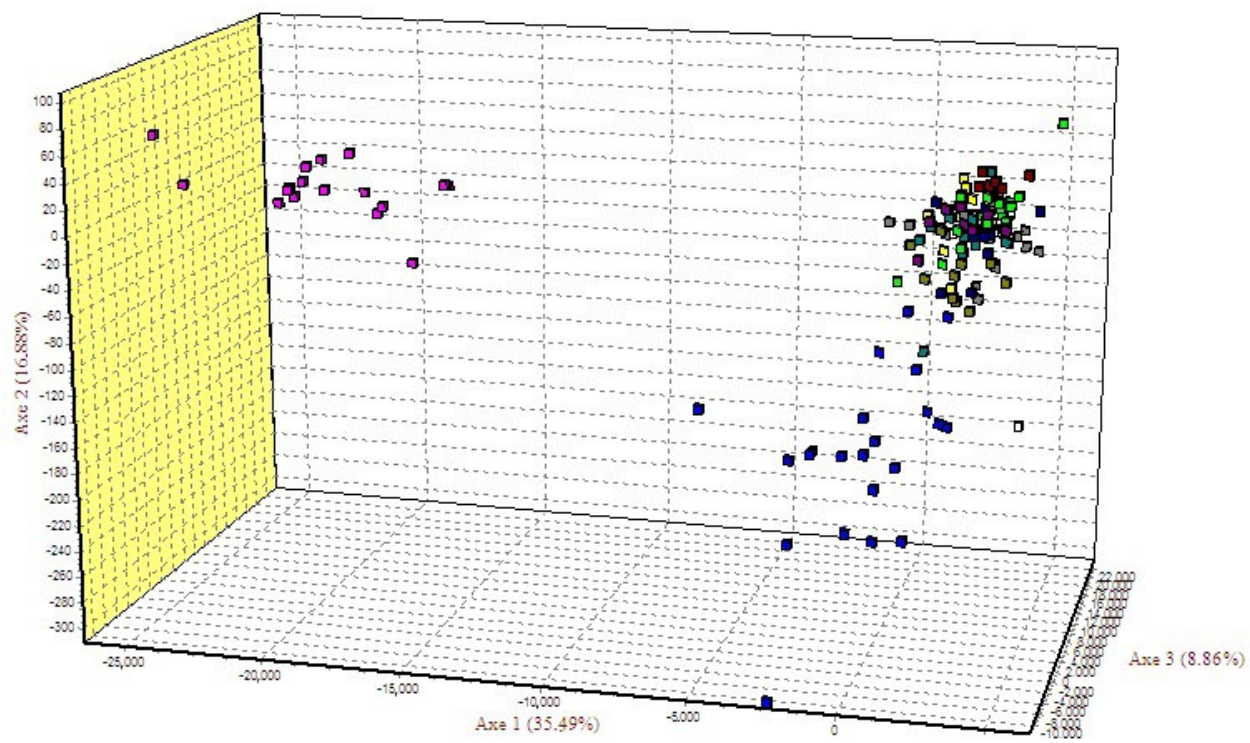

Figure 1. Factorial correspondence analysis in Blanco Orejinegro and Zebu cattle populations.

\section{Genetic distances between BON breed populations}

This study calculated the Nei's standard genetic distance (Nei et al., 1983) between the 10 commercial populations, with Figure 2 depicting the genetic distances. Nei distances showed that the most distant populations in this study were the EP and BH herds (0.91); similarly the JP and BG populations displayed a high genetic distance value (0.84), as did the HV and EP herds (0.63). The results indicated that these populations shared few alleles and that the frequency of alleles shared between them were very different, suggesting genetically distant populations. Conversely, the lowest genetic distance values between populations were found between HV and AZ (0.15) and, as expected, BH and AZ populations (0.193). These populations were geographically close and had recently shared bulls. Moreover, a low genetic distance was found between the BH and UNAL populations (0.17). A similar distance was found between the populations AZ and LE (0.199). 


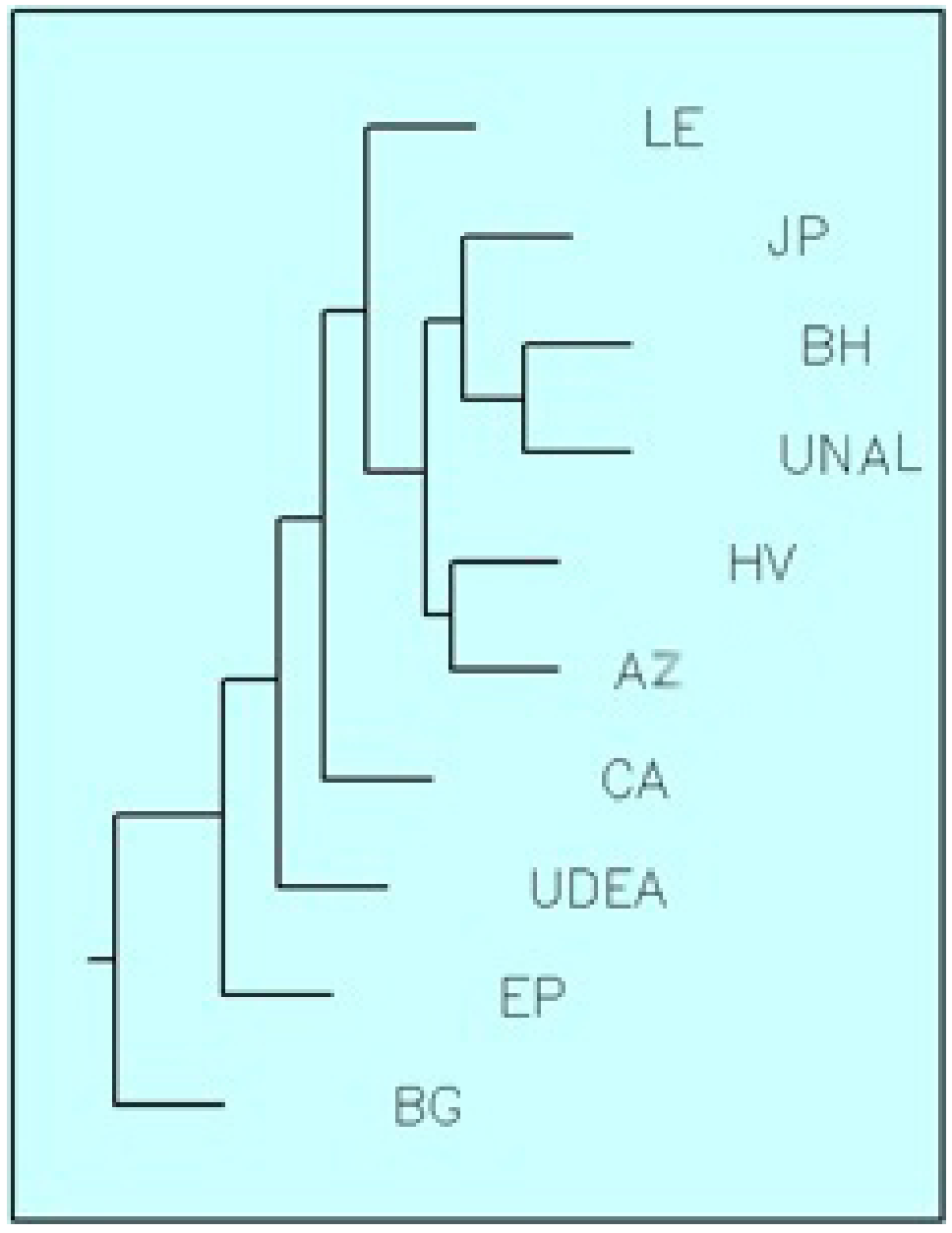

Figure 2. Dendrogram using the Nei method to calculate distances between populations of the Blanco Orejinegro breed using neighbor-joining algorithm in the Phylip ${ }^{\circledR}$ program with bootstrapping of 1000 replicates. For abbreviations, see legend to Table 1.

\section{Genetic structure and admixture analysis}

The Structure version 2.1 program (Pritchard et al., 2000) was used with a Bayesian algorithm to determine the posterior distribution of the membership coefficient of each individual (Q). The mean of this distribution represents an estimate of the proportion of the genetic profile of an individual belonging to any of the possible populations in the group analysis, assuming that these are in Hardy-Weinberg equilibrium. In other words, this procedure performs the assignment of individuals to populations (clusters) based on their genetic similarity assuming that gene frequencies are correlated and that the populations under study are mixed. For each value of $\mathrm{K}$ (number of populations) there were 5000 replicates. The results of each run are based on 10,000 iterations. 
The results of this analysis for each individual are shown in Figure 3, where each individual is represented by a vertical bar divided into $\mathrm{K}$ segments of different color. When the bar has a single color, this means that the genetic profile of that individual is assigned a $100 \%$ probability to a single cluster $(\mathrm{K})$, according to the alleles present and their frequencies in a given individual. A bar of 2 or more colors signifies an assignment to 2 or more populations, which indicates shared traits with more than 1 population $(\mathrm{K})$.

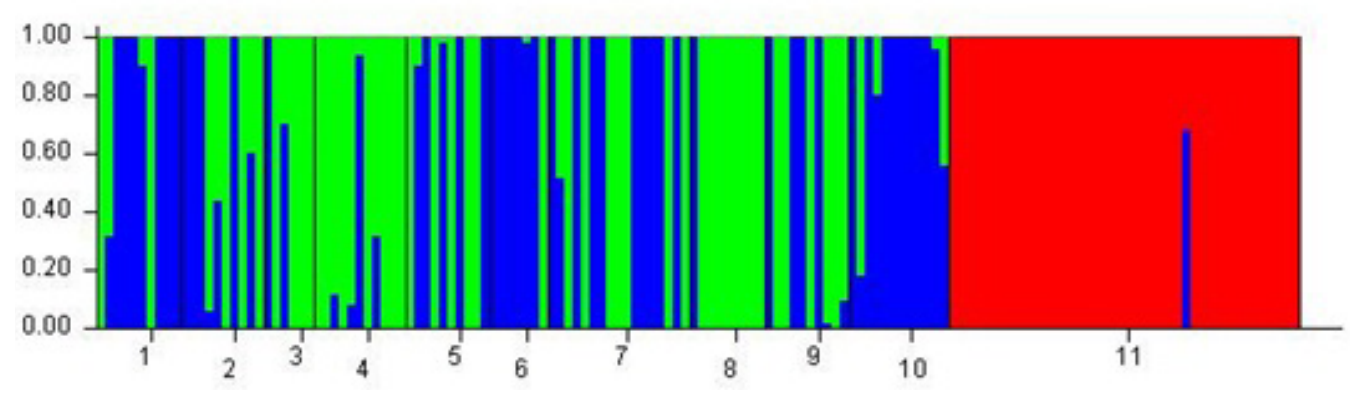

Figure 3. Bar representation and cluster assignment of the STRUCTURE analysis for 10 populations of Blanco Orejinegro. Population $11=$ Zebu herd.

The simulation analysis included a total of 144 individuals, 102 BON breed animals and 42 Zebu animals. The analysis resulted in the clustering of 3 populations $(K=3)$ in this study. Population 1 clearly defined the population representing the individuals from the Zebu breeds (red - K1) while the other two populations identified (green - K2 and blue - K3) were from the BON individuals sampled, indicating two distinct groups within the BON breed. The Zebu animals had a defined population structure with $98.4 \%$ of Zebu individuals clustered completely in population 1 . However, population 1 individuals shared genetic profiles with both the Zebu cluster and one of the BON clusters.

The populations $\mathrm{CA}$, UNAL, HV, and $\mathrm{BH}$ were grouped in cluster $\mathrm{K} 2$ identified with the green color, and populations LE, UDEA, AZ, BG, and JP were grouped in cluster K3 identified with the blue color. It was notable that these showed more variation and that the likelihood estimators were consistent across separate runs.

The population of UDEA showed a membership value of $88.9 \%$, which mainly comprised the green cluster, and likewise $85.4 \%$ of the animals in population JP and $87.5 \%$ of the animals in population BG were located in the blue cluster. The individuals from populations EP and CA had membership values that mainly clustered in the group identified by the green color ( 86.7 and $71.7 \%$ for EP and CA, respectively). The $F_{\mathrm{ST}}$ values were recalculated, taking into account the populations analyzed (10 populations of breed BON and one of Zebu), and also according to the simulation of three clusters $(\mathrm{Q}=3)$. The highest value of $F_{\text {ST }}$ was found in the $\mathrm{K} 1$ group $(0.1468)$, corresponding to the cluster in which individuals were mainly populations of Zebu breeds. K2 on the other hand showed a lower value $\left(F_{\text {ST }}\right.$ $=0.0636$ ), which mainly represented individuals with predominant genetic profile, and the $\mathrm{K} 3$ group had a similar value $\left(F_{\mathrm{ST}}=0.0578\right)$, indicating that these two subgroups could be of the same grouping. 


\section{DISCUSSION}

Two components are used to characterize variability in animal genetic resources: phenotypic variability, which is easy to see and can be measured directly on individuals, and genetic variability, which can be measured in the variations in DNA sequence by means of different genetic markers. In both cases, there are mathematical tools that allow us to adequately characterize the variability within and between populations.

\section{Microsatellite diversity}

The average $N_{\mathrm{A}}$ observed at each locus, consolidating data for all 10 herds, was higher than estimates found in other studies (Russell et al., 2000; Beja-Pereira et al., 2003; Mateus et al., 2004; Ibeagha-Awemu and Erhardt, 2005). The genotype data obtained showed that significant amounts of genetic variation are maintained in the Colombian Creole cattle populations. The BON Creole breed displayed a distinctly high allelic richness, nominally higher than that of the zebuine breeds, most likely resulting from mild selection pressure and a more liberal pattern of herd management. Our results are consistent with the observations of Lirón et al. (2006), who found Creole cattle populations to have a relatively high level of genetic variation as estimated by allelic diversity and heterozygosity, as compared to taurine and zebuine breeds. Despite the Zebu breed exhibiting an intermediate allelic diversity, these animals showed the lowest gene diversity.

Several markers displayed a significant deficit of heterozygotes due to within-population inbreeding. Such results have been commonly observed in similar studies of cattle breeds in other countries (Maudet et al., 2002; Beja-Pereira et al., 2003; Lirón et al., 2006). The occurrence of null alleles and genotyping errors could also lead to a deficiency of heterozygotes. However, the estimates of deficit of heterozygotes for the same marker locus varied by subspecies, and the set of microsatellites used has been carefully recommended and broadly used for diversity surveys worldwide (Martin-Burriel et al., 1999).

In the BON breed, $H_{\mathrm{E}}$ displayed a similar value $(0.73)$ as that found in other Creole cattle populations such as the Uruguayan Creole breed $\left(H_{\mathrm{E}}=0.67\right)$ (Armstrong et al., 2004), Florida Craker, Pineywoods Texas Longhorn in USA $\left(H_{\mathrm{E}}=0.7\right)$ (McNeil et al., 2006) or the Creole breed Casanare in Colombia $\left(H_{\mathrm{E}}=0.82\right)$ (Barrera et al., 2006).

The value of genetic diversity or $H_{\mathrm{E}}$ in populations of the Colombian breed BON was higher than that found in other breeds such as Simmental $\left(H_{\mathrm{E}}=0.58\right)$ (Edwards et al., 2000), Nelore $\left(H_{\mathrm{E}}=0.51\right)$ (Lara et al., 2005), the Highland breed $\left(H_{\mathrm{E}}=0.57\right)$, Hereford $\left(H_{\mathrm{E}}=0.60\right)$, and Shorthorn $\left(H_{\mathrm{E}}=0.58\right)$ (McNeil et al., 2006), indicating that because of intensive selection these populations have become more homozygous.

To quantify the genetic variability in the Colombian cattle breed BON, 12 microsatellites were used resulting in an $F_{\text {IS }}$ value of intermediate magnitude (0.09), showing that the BON breed has undergone moderate inbreeding, indicating a significant proportion of heterozygous alleles.

Genetic diversity values obtained in the BON breed were significantly higher than that observed in the Blanca Cacereña, Charolais and Retinta breeds (Padilla et al., 2009), similar to other highly inbred endangered breeds, e.g., Mallorquina breed (Martin-Burriel et al., 2003) and Betizu breed (Rendo et al., 2004). From a practical point of view, the promotion of vari- 
ability within breeds is useful in the processes of selection and adaptation, while giving more importance to the variability between breeds is more reasonable when the aim is to exploit the results of crosses (Garcia and Cañón, 2007).

When a process of genetic isolation persists for several generations, the main consequence, from the point of view of population genetics, is inbreeding and genetic drift (Falconer and Mackay, 1996).

Compared with other studies, the PIC values obtained are similar to those described by Arranz (1994) and Rodellar et al. (1996) for Spanish cattle populations, where the ETH 225 marker was found to be highly informative in the Galician Blonde breed, which is consistent with the results obtained in our study.

Also, Zamorano et al. (1998) reported for the same markers, PIC values lower than those obtained in this study $(\mathrm{BM} 1818=0.56, \mathrm{BM} 1824=0.62, \mathrm{ETH} 10=0.70, \mathrm{ETH} 225=$ 0.45 , and INRA063 $=0.35$ ). This could have been due to a difference in sample size. These authors used 119 animals, whereas the present study included 139 individuals. Aquino et al. (2008) also found lower PIC values for BM1818, BM1824 and ETH225, 0.76, 0.721 and 0.76, respectively.

\section{Statistical analysis}

Several studies have proven the STRUCTURE software to be efficient in assigning individuals to their populations of origin (Beaumont et al., 1998; Randi et al., 2001; Rosenberg et al., 2001; Barilani et al., 2005). Nevertheless, the ability of STRUCTURE to detect the true number of clusters $(\mathrm{K})$ has been questioned when low levels of population differentiation exist (Latch et al., 2006). In this sense, Pritchard et al. (2000) showed that STRUCTURE easily detects highly differentiated populations.

The assignment of individuals to the clusters defined by the STRUCTURE program confirmed the genetic differentiation between populations of BON, but also allowed us to recognize the separation of individuals into three different and homogeneous groups. It is also clear that when considering a greater number of groups $(K=6)$, the populations $\mathrm{AZ}$ and $\mathrm{BH}$ are both genetically homogeneous populations. The general relationship between these two populations can be explained by the close genetic origin of $\mathrm{BH}$ and $\mathrm{AZ}$, since both populations belong to the same family.

Nevertheless, the utilization of larger numbers of markers with higher variation in additional population samples may enable a better definition of the differences between populations as well as better estimates of membership (Seldin et al., 2006).

Besides microsatellite markers, the examination of population differences within the Creole cattle BON using a subset of informative SNPs, mitochondrial markers or Y-chromosomal markers, may be particularly useful in tracing part of the routes of migration and admixture of the cattle populations.

The results of this survey of genetic variation and structure in the Creole cattle BON breed illustrate the potential for microsatellite analysis to reveal subtle aspects of the genetic history of closely related populations. In addition, these analyses indicate that models of microsatellite evolution based on stepwise mutation processes are not necessarily the most appropriate for studies of genetic micro-differentiation. 


\section{ACKNOWLEDGMENTS}

Research supported by the Ministerio de Agricultura y Desarrollo Rural (under Agreement \#057). We thank all the stockbreeders of BON who provided the samples necessary to carry out this study.

\section{REFERENCES}

Aquino YN, Veli EA, Rivas Seoane E, Rivas Palma V, et al. (2008). Variabilidad genética de bovinos criollos de perú utilizando marcadores microsatélites. Arch. Zootec. 57: 337-340.

Armstrong E, Postiglioni A, Martínez A, Rincón G, et al. (2004). Reserva genética de bovinos Criollos del Parque Nacional de San Miguel. I Análisis Genético de Toros con Microsatélites. Veterinaria 39 (155-156): 33-38.

Arranz JJ (1994). Estudio Genético en Poblaciones Bovinas Mediante Polimorfismos Bioquímicos y de DNA (Variaciones puntuales y Microsatélites). Doctoral thesis, Universidad de León, Facultad de Veterinaria, León.

Asocriollo (2003). Razas Criollas Y Colombianas Puras. Ganado Criollo Blanco Orejinegro. In: Razas Criollas Y Colombianas Puras (Gutiérrez ID, ed.). MADR-Asocriollo, Madrid, 58-73.

Barilani M, Deregnaucourt S, Gallego S, Galli L, et al. (2005). Detecting hybridization in wild (Coturnix c. coturnix) and domesticated (Coturnix c. japonica) quail populations. Biol. Conserv. 126: 445-455.

Barrera GP, Martinez R, Perez J, Polanco N, et al. (2006). Evaluación de la variabilidad genética en ganado criollo colombiano mediante 12 marcadores microsatélites. AGRI 38: 35-45.

Beaumont MA, Ibrahim KM, Boursot P and Bruford MW (1998). Measuring Genetic Distance. In: Molecular Tools for Screening Biodiversity Plants and Animals (Karp A, Isaac PG and Ingram DS, eds.). Chapman and Hall, London, 315-326.

Beja-Pereira A, Alexandrino P, Bessa I, Carretero Y, et al. (2003). Genetic characterization of southwestern European bovine breeds: a historical and biogeographical reassessment with a set of 16 microsatellites. J. Hered. 94: 243-250.

Belkhir K, Borsa P, Chikhi L, Raufaste N, et al (2003). Genetix v. 4.04, Logiciel sous Windows ${ }^{\mathrm{TM}}$ pour la Genetique des Populations. Laboratoire Genome et Population, Universite Montpellier 2, Montpellier.

Botstein D, White RL, Skolnick M and Davis RW (1980). Construction of a genetic linkage map in man using restriction fragment length polymorphisms. Am. J. Hum. Genet. 32: 314-331.

Bruford MW, Bradley DG and Luikart G (2003). DNA markers reveal the complexity of livestock domestication. Nat. Rev. Genet. 4: 900-910.

Cañón J, Alexandrino P, Bessa I, Carleos C, et al. (2001). Genetic diversity measures of local European beef cattle breeds for conservation purposes. Genet. Sel. Evol. 33: 311-332.

Edwards CJ, Dolf G, Looft C, Loftus RT, et al. (2000). Relationships between the endangered Pustertaler-Sprinzen and three related European cattle breeds as analysed with 20 microsatellite loci. Anim. Genet. 31: 329-332.

Falconer DS and Mackay TF (1996). Introducción a la Genética Cuantitativa. Editorial Acribia, Zaragosa.

FAO (2011). Molecular Genetic Characterization of Animal Genetic Resources. FAO Animal Production and Health Guidelines. No. 9. Rome.

Felsenstein J (2004). Inferring Phylogenies. Sinauer Associates, Inc., Sunderland.

García D and Cañón J (2007). Diversidad de las especies de animales domésticos: Importancia y conservación de la variabilidad genética. FEAGAS 31: 61-66.

Goldstein DB and Schlötterer C (1999). Microsatellites: Evolution and Applications. Oxford University Press, Oxford.

Hall SJG and Ruane J (1993). Livestock breeds and their conservation: a global overview. Conserv. Biol. 7: 815-825.

Hanotte O, Bradley DG, Ochieng JW, Berjee Y, et al. (2002). African pastoralism: genetic imprints of origins and migrations. Science 296: 336-339.

Ibeagha-Awemu EM and Erhardt G (2005). Genetic structure and differentiation of 12 African Bos indicus and Bos taurus cattle breeds, inferred from protein and microsatellite polymorphisms. J. Anim. Breed. Genet. 122: 12-20.

Kantanen J, Olsaker I, Holm LE, Lien S, et al. (2000). Genetic diversity and population structure of 20 North European cattle breeds. J. Hered. 91: 446-457.

Lara MA, Contel EP and Sereno JR (2005). Caracterización genética de poblaciones cebuínas a través de marcadores moleculares. Arch. Zootec. 54: 295-303.

Latch EK, Dharmarajan G, Glaubitz JC and Rhodes OE Jr (2006). Relative performance of Bayesian clustering software for inferring population substructure and individual assignment at low levels of population differentiation. Conserv. Biol. 7: 295-302. 
Lirón JP, Peral-Garcia P and Giovambattista G (2006). Genetic characterization of Argentine and Bolivian cattle breeds assessed through microsatellites. J. Hered. 97: 331-339.

Martin-Burriel I, Garcia-Muro E and Zaragoza P (1999). Genetic diversity analysis of six Spanish native cattle breeds using microsatellites. Anim. Genet. 30: 177-182.

Martin-Burriel I, Osta R, Puigserver G, Rodellar C, et al. (2003). Primeros Estudios de Caracterización Genética de la Raza Bovina Mallorquina. Laboratorio de Genética Bioquímica Facultad de Veterinaria, Universidad de Zaragoza Miguel Servet, Zaragoza.

Mateus JC, Penedo MC, Alves VC, Ramos M, et al. (2004). Genetic diversity and differentiation in Portuguese cattle breeds using microsatellites. Anim. Genet. 35: 106-113.

Maudet C, Luikart G and Taberlet P (2002). Genetic diversity and assignment tests among seven French cattle breeds based on microsatellite DNA analysis. J. Anim. Sci. 80: 942-950.

McNeil MD, Cronin MA, Blackburn HD and Alexander LJ (2006). Genetics Relationships Among Breeds of Beef Cattle in the United States that Originated from the British Islands, Iberian Peninsula or West-Central Europe. 8th Congress on Genetics Applied to Livestock Production, Belo Horizonte.

Nei M (1972). Genetic distances between populations. Am. Nat. 106: 283-292.

Nei M, Tajima F and Tateno Y (1983). Accuracy of estimated phylogenetic trees from molecular data. II. Gene frequency data. J. Mol. Evol. 19: 153-170.

Notter DR (1999). The importance of genetic diversity in livestock populations of the future. J. Anim. Sci. 77: 61-69.

Padilla JA, Sansinforiano E, Parejo JC, Rabasco A, et al. (2009). Inference of admixture in the endangered Blanca Cacereña bovine breed by microsatellite analyses. Livest. Sci. 122: 314-322.

Park SDE (2001). Trypanotolerance in West African Cattle and the Population Genetic Effects of Selection. Ph.D thesis, University of Dublin, Dublin.

Pritchard JK, Stephens M and Donnelly P (2000). Inference of population structure using multilocus genotype data. Genetics 155: 945-959.

Randi E, Pierpaoli M, Beaumont M, Ragni B, et al. (2001). Genetic identification of wild and domestic cats (Felis silvestris) and their hybrids using Bayesian clustering methods. Mol. Biol. Evol. 18: 1679-1693.

Rendo F, Iriondo M, Jugo BM, Aguirre A, et al. (2004). Analysis of the genetic structure of endangered bovine breeds from the Western Pyrenees using DNA microsatellite markers. Biochem. Genet. 42: 99-108.

Rodellar C, Martin-Burriel Y, Cons C and Zarazaga I (1996). Genetic Structure and Distances Between three Spanish Bovine Breeds Using INRA05, INRA063, ETH3, ETH10, ETH225 and LSTS005 Microsatellites. Proceedings of the 25th International Society for Animal Genetics, Tours.

Rosenberg NA, Burke T, Elo K, Feldman MW, et al. (2001). Empirical evaluation of genetic clustering methods using multilocus genotypes from 20 chicken breeds. Genetics 159: 699-713.

Russell ND, Rios J, Erosa G, Remmenga MD, et al. (2000). Genetic differentiation among geographically isolated populations of Criollo cattle and their divergence from other Bos taurus breeds. J. Anim. Sci. 78: 2314-2322.

Saitou N and Nei M (1987). The neighbor-joining method: a new method for reconstructing phylogenetic trees. Mol. Biol. Evol. 4: 406-425.

Seldin MF, Shigeta R, Villoslada P, Selmi C, et al. (2006). European population substructure: clustering of northern and southern populations. PLoS Genet. 2: e143.

Toro MA (2008). Genetic distances: a useful tool to be applied with caution. J. Anim. Breed. Genet. 125: 3-4.

Zamorano MJ, Ruiter J, Rodero A and Vega JL (1998). Análisis genético de marcadores microsatélites en dos poblaciones de la raza bovina berrenda en negro. Arch. Zootec. 47: 195-200. 